\section{OPEN ACCESS}

Edited by:

Marc Jean Struelens, Université libre de Bruxelles, Belgium

Reviewed by:

Timotius Ivan Hariyanto, University of Pelita Harapan, Indonesia

Liberata Sportiello,

Università della Campania Luigi Vanvitelli, Italy

*Correspondence: Yeganeh Farsi yeganehfarsi@sbmu.ac.ir Mohammad Javad Nasiri

mj.nasiri@hotmail.com

Specialty section: This article was submitted to Infectious Diseases - Surveillance,

Prevention and Treatment

a section of the journal

Frontiers in Medicine

Received: 27 June 2021

Accepted: 25 August 2021

Published: 20 September 2021

Citation:

Sodeifian F, Seyedalhosseini ZS,

Kian N, Eftekhari M, Najari S, Mirsaeidi $M$, Farsi Y and Nasiri MJ (2021) Drug-Induced Liver Injury in COVID-19 Patients: A Systematic

Review. Front. Med. 8:731436 doi: 10.3389/fmed.2021.731436

\title{
Drug-Induced Liver Injury in COVID-19 Patients: A Systematic Review
}

\begin{abstract}
Fatemeh Sodeifian ${ }^{1}$, Zahra Sadat Seyedalhosseini ${ }^{1}$, Naghmeh Kian ${ }^{2}$, Mahya Eftekhari ${ }^{2}$, Shaghayegh Najari ${ }^{3}$, Mehdi Mirsaeidi ${ }^{4,5}$, Yeganeh Farsi ${ }^{1 *}$ and Mohammad Javad Nasiri ${ }^{6 *}$

${ }^{1}$ Student Research Committee, School of Medicine, Shahid Beheshti University of Medical Sciences, Tehran, Iran, ${ }^{2}$ School of Medicine, Shahid Beheshti University of Medical Sciences, Tehran, Iran, ${ }^{3}$ School of Dentistry, Shahid Beheshti University of Medical Sciences, Tehran, Iran, ${ }^{4}$ Division of Pulmonary and Critical Care, Department of Medicine, University of Miami Miller School of Medicine, Miami, FL, United States, ${ }^{5}$ Department of Pulmonary and Critical Care, Miami VA Medical Center, Miami, FL, United States, ${ }^{6}$ Department of Microbiology, School of Medicine, Shahid Beheshti University of Medical Sciences, Tehran, Iran
\end{abstract}

Introduction: The severity of COVID-19 may be correlated with the risk of liver injury development. An increasing number of studies indicate that degrees of hepatotoxicity has been associated with using some medications in the management of COVID-19 patients. However, limited studies had systematically investigated the evidence of drug-induced liver injury (DILI) in COVID-19 patients. Thus, this study aimed to examine DILI in COVID-19 patients.

Methods: A systematic search was carried out in PubMed/Medline, EMBASE, and Web of Science up to December 30, 2020. Search items included "SARS-CoV-2", "Coronavirus," COVID-19, and liver injury.

Results: We included 22 related articles. Among included studies, there was five case report, five case series, four randomizes control trial (RCT), seven cohort studies, and one cross-sectional study. The drugs included in this systematic review were remdesivir, favipiravir, tocilizumab, hydroxychloroquine, and lopinavir/ritonavir. Among included studies, some studies revealed a direct role of drugs, while others couldn't certainly confirm that the liver injury was due to SARS-CoV-2 itself or administration of medications. However, a significant number of studies reported that liver injury could be attributable to drug administration.

Discussion: Liver injury in COVID-19 patients could be caused by the virus itself or the administration of some types of drug. Intensive liver function monitoring should be considered for patients, especially patients who are treated with drugs such as remdesivir, lopinavir/ritonavir, and tocilizumab.

Keywords: COVID-19, SARS-CoV-2, drug induced liver injury (DILI), liver injury, adverse drug reaction

\section{INTRODUCTION}

Today, Severe Acute Respiratory Syndrome Coronavirus 2 (SARS-CoV-2) infection, causing the pandemic Coronavirus Disease 2019 (COVID-19), a novel acute respiratory disease, which has affected 220 countries and territories with more than 200 million infected individuals and more than 4 million deaths, has become a serious global health concern. 
With the main clinical manifestations of cough, fever, and shortness of breath (1), and the respiratory tract being the leading site of infection, the course of the disease is complex in a portion of the cases, in which it involves multi-organ including liver (2). As angiotensin-converting enzyme 2 (ACE2) is the central receptor for SARS-CocV-2 entry to the host cells $(3,4)$, its wide distribution in different body tissues can explain multi-organ involvement in COVID-19. Epidemiological studies (3) indicate different degrees of elevated liver chemistries with an incidence of $24.4 \%$, particularly in liver transaminases, Aspartate transaminase (AST), and Alanine aminotransferase (ALT) in COVID-19 patient (5). COVID-19 associated liver injury, defined as any damage that occurred to the liver due to pathogenesis or treatment of COVID-19 (6), has been reported to occur in $20-46.9 \%$ of the COVID-19 patient $(7,8)$.

It's been shown that the severity of COVID-19 is correlated with the risk of liver injury development $(8,9)$. Furthermore, it's been suggested that liver injury is associated with poor outcomes of SARS infection, which is still a matter of debate $(10,11)$. Besides, the CT-quantified liver/spleen attenuation ratio has further proved the liver damage in COVID-19 patients, which was correlated with the severity of the disease (12). In previous studies, SARS-CoV viral particles have been identified in hepatocytes (13), and direct induction of liver injury by SARS$\mathrm{CoV}$ was observed in vitro (14). In addition, SARS-CoV-2 is also shown to be associated with Liver tissue damage and dysfunction (15). While being mild in most cases, these liver manifestations of COVID-19 can potentially cause some adverse effects, from blood coagulation abnormalities causing severe bleeding to liver failure and even death caused by liver function deterioration (1517). Hence, it is essential to find out the underlying mechanisms of these liver manifestations to prevent such adverse effects.

Since its initial rise in December 2019, various therapeutic compounds have been used to control the progression of pathogenesis and symptoms in the course of COVID-19. This drug armamentarium consists of several groups: (1) Antiviral drugs, including remdesivir, lopinavir/ritonavir, favipiravir, triazavirin, and umifenovir, (2) Antibiotics, including azithromycin and ceftriaxone, (3) Antimalarials, mainly hydroxychloroquine, (4) Immunomodulator agents, including tocilizumab and steroids like Dexamethasone, (5) antipyretic medications like acetaminophen, and (6) other adjunctive treatments like zinc sulfate and vitamin $\mathrm{C}$, and several investigational treatments including convalescent plasma administration from COVID-19 recovered individuals and high-dose anakinra (an IL-1 $\beta$ inhibitor) (18). Previously some degrees of hepatotoxicity have been reported for many of these therapeutic agents as they were used for other diseases like viral infections.

An increasing number of studies indicate that degrees of hepatotoxicity have been associated with using some of these medications in the management of COVID-19 patients. Significantly, it was relieved after the cease of these agents. However, to our best knowledge, no studies had systematically investigated the evidence of drug-induced liver injury (DILI) in COVID-19 patients until today. In this study, to elucidate the association between hepatotoxicity in COVID-19 patients and the drugs used in these patients and to better identify the role of DILI as a possible mechanism of hepatotoxicity, the currently available evidence on the association of different therapeutic agents with hepatotoxicity in COVID-19 patient was systematically reviewed.

\section{METHODS}

This systematic review was conducted based on the "Preferred Reporting Items for Systematic Reviews and Meta-Analyses" (PRISMA) statement (19).

\section{Search Strategy}

Our team performed systematic literature searches through PubMed/Medline, Web of Science, and Embase databases. We included case reports and case series for the article type published until January 2021. Search items included "SARS-CoV2", "Coronavirus", "COVID-19", and "liver injury". We included studies written in English.

\section{Eligibility Criteria}

We reviewed any studies reporting liver injury and liverrelated adverse events caused by drug administration in COVID19 patients including case reports, case series, case- controls, cohorts, clinical trials and observational studies. Definite adult cases of COVID-19 (mainly via a positive COVID-19 PCR) whom were hospitalized considered as the target population of our study. The studies that reported liver injury due to SARSCoV-2 were not included in this study.

\section{Study Selection}

To find eligible articles, we screened potentially valid papers through two steps, step one reviewing the title and the abstract of the articles, and step two, reviewing the full text of the qualified articles from the first step. In both steps, each article was screened by two reviewers independently. If any ambiguity or disagreement was met, it was discussed among authors, and a final decision was made.

\section{Data Extraction}

We extracted the following as data: first author, publication year, type of study, the country was the study was conducted, mean age, medications, COVID-19 symptoms, patients comorbidities, inclusion and exclusion criteria, number of charged/discharged patients, the severity of COVID-19 disease, and laboratory liver function tests. In addition, we extracted demographic data of patients in the medication group but not in the placebo group. Similarly, for this step, each article data sheet was completed and reviewed by two authors independently, and disagreements and technical uncertainties were resolved through discussion with a third reviewer.

\section{RESULTS}

\section{Study Characteristics}

The selection process of articles is shown in Figure 1. Finally, we included 22 related articles. Among included studies, there 


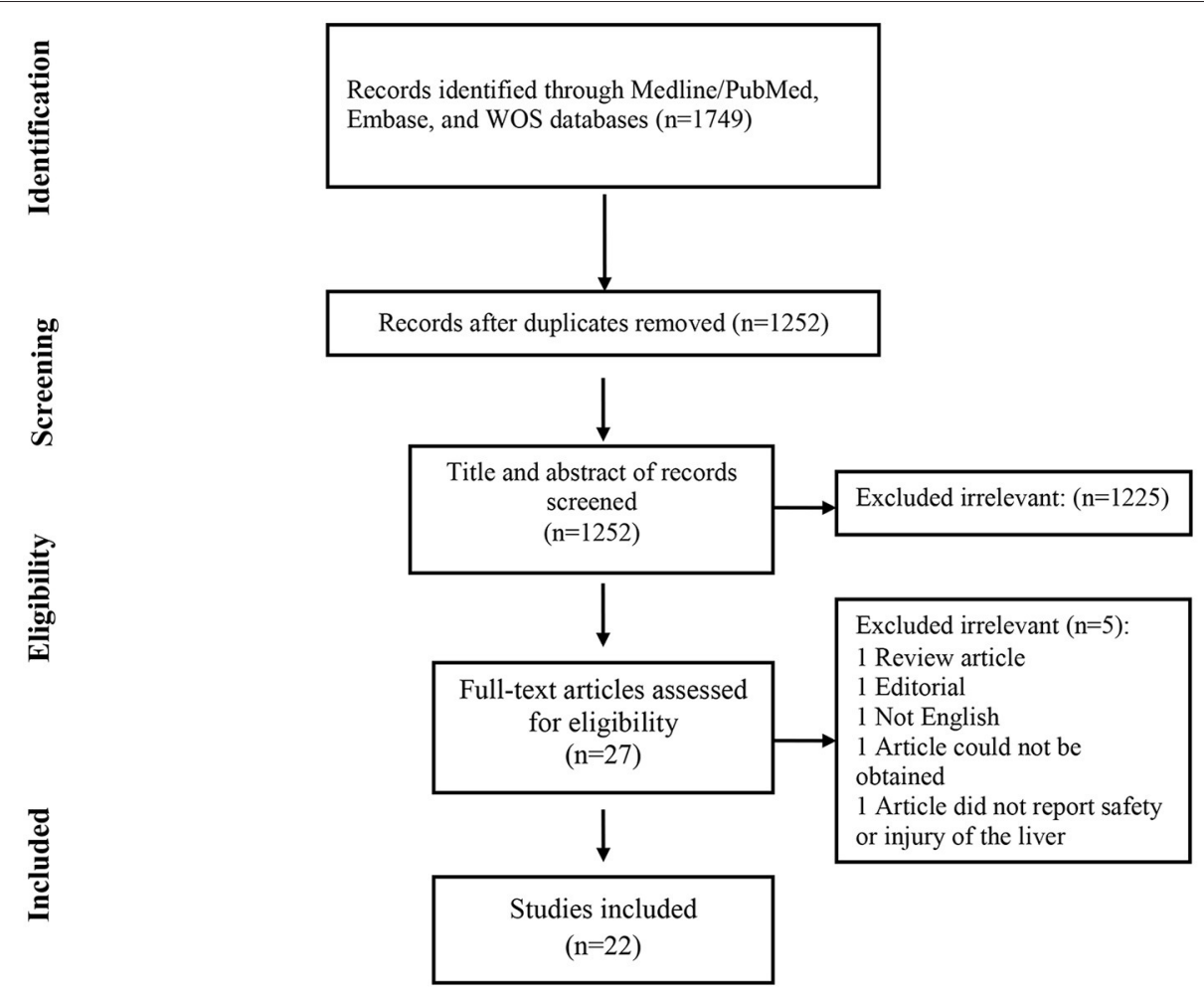

FIGURE 1 | Flow chart of study selection for inclusion in the systematic review.

was five case report, five case series, four randomizes control trial (RCT), seven cohort studies, and one cross-sectional study. In addition, six studies were from China, five studies from Italy, four studies from the USA, one study from Korea, one study from Brazil, one study from Ireland, one study from the Netherlands, one study from Montenegro, one study from India, and one study from Japan. The majority of included studies (11 studies) evaluated the safety of remdesivir for liver function, six studies reported safety of lopinavir/ritonavir, three studies assessed the safety of tocilizumab, three studies reported the safety of hydroxychloroquine. In addition, two studies showed the safety of favipiravir for liver function (Table 1).

\section{Drug-Induced Liver Injury -Remdesivir}

The first study reporting the safety of remdesivir for COVID-19 patients, conducted by Grein et al., investigated the effect of 5 to 10 -days courses of remdesivir on the changes in the category of oxygen-support status in a small cohort of 53 patients. The most common adverse event in this study was increased hepatic enzymes by an incidence of $23 \%$. Moreover, one of the four patients who discontinued the treatment was due to the elevated liver aminotransferase (20). A similar pattern was replicated in the study on 402 patients, evaluating the optimum time-course for intravenous remdesivir, conducted by Goldman et al. In that grade, 1-2 ALT and AST elevation (7 and 6\% respectively) was reported as the most common liver adverse effects (27).
Furthermore, in the placebo-controlled double-blinded clinical trial on a total sample of 255 patients, conducted by Wang et al., grade 1-2 Increased AST was detected as an adverse liver effect (12\% in the placebo group, $7 \%$ in remdesivir group; or $12: 7 \%)$ and grade $1-2$ increased ALT led to drug discontinuation (1\%). However, the most common liver adverse effects reported by the same study were grade 1-2 hypoalbuminemia (15:13\%) and grade 1-2 increased bilirubin (9:10\%) respectively, latter of which also caused drug discontinuation (1\%) (23). In an exciting perspective open-labeled study, remdesivir induced adverse effects were compared between patients in an intensive care unit (ICU) and infectious disease wards (IDW). While aminotransferase elevation was almost equal among the two groups $(\mathrm{ICU}=44.4 \%$; IDW $=41.2 \%$ ), bilirubin elevation was more probable in ICU rather than IDW patients, suggesting that the differences in the incidence of different adverse effects among further studies may be due to the different severity states of COVID-19 in the patients (24). In addition to this line of studies, there are also some case reports. In a recent one, an acute increase in ALT was reported after 2 days of remdesivir initiation and was corrected immediately following the stop of remdesivir (32). In two other case reports, hepatic enzyme elevation was detected in patients receiving remdesivir with or without HCQ, who were previously treated with lopinavir/ritonavir $(35,36)$. In another case report, Carothers et al. have suggested that the use of acetylcysteine can be beneficial in the management of acute liver failure (ALF) induced by remdesivir (38). 
TABLE 1 | Characteristics of included studies.

\begin{tabular}{|c|c|c|c|c|c|c|c|c|c|c|c|c|c|c|}
\hline $\begin{array}{l}\text { First } \\
\text { Author }\end{array}$ & Country & $\begin{array}{l}\text { Date of } \\
\text { publication }\end{array}$ & Type of study & $\begin{array}{l}\text { Sample } \\
\text { size }\end{array}$ & $\begin{array}{l}\text { Male: } \\
\text { Female }\end{array}$ & $\begin{array}{c}\text { Mean } \\
\text { age }\end{array}$ & Nationality & MEDICATIONS & Inclusion criteria & Exclusion criteria & $\begin{array}{l}\text { Severity of } \\
\text { disease } \\
\text { (mild, mod, } \\
\text { severe) }\end{array}$ & Complications & $\begin{array}{l}\text { COVID-19 } \\
\text { symptoms }\end{array}$ & Discharge \\
\hline $\begin{array}{l}\text { Fan et al. } \\
(17)\end{array}$ & China & 10-Apr-20 & $\begin{array}{l}\text { retrospective } \\
\text { cohort study }\end{array}$ & 148 & $\begin{array}{l}73 \mathrm{M} \\
75 \mathrm{~F}\end{array}$ & 50 & Chinese & lopinavir/ ritonavir & $\begin{array}{l}\text { Clinical criteria of discharge } \\
\text { and diagnosis were } \\
\text { according to the standards } \\
\text { for "Diagnosis and } \\
\text { Treatment Scheme of New } \\
\text { Coronavirus Infected } \\
\text { Pneumonia" (trial version } \\
\text { 6), history of exposure and } \\
\text { most had clinical } \\
\text { manifestations including } \\
\text { fever or respiratory } \\
\text { symptoms }\end{array}$ & & severe (10) & - & $\begin{array}{l}\text { fever in } 127, \\
\text { cough in } 67, \\
\text { Diarrhea in } 6, \\
\text { Nausea and } \\
\text { vomiting in } 3, \\
\text { expectoration } \\
\text { in } 38, \\
\text { asymptomatic } \\
\text { in } 5 \text {, other liver } \\
\text { disease in } 9\end{array}$ & 92 \\
\hline $\begin{array}{l}\text { Grein } \\
\text { et al. (20) }\end{array}$ & USA & 10-Apr-20 & $\begin{array}{l}\text { cohort, } \\
\text { compassionate- } \\
\text { use }\end{array}$ & 53 & $\begin{array}{l}40 \mathrm{M}, \\
13 \mathrm{~F}\end{array}$ & 64 & $\begin{array}{l}\text { United States, } \\
\text { Japan, Italy, } \\
\text { Austria, France, } \\
\text { Germany, } \\
\text { Netherlands, } \\
\text { Spain, Canada }\end{array}$ & remdesivir & $\begin{array}{l}\text { COVID-19 infection } \\
\text { confirmed by } \\
\text { RT-PCR,needing O2 } \\
\text { support or O2 Sat } \leq 94 \% \\
\text { while breathing ambient air, } \\
\text { creatinine clearance }>30 \\
\mathrm{~mL} / \mathrm{min} \text {, serum AST and } \\
\text { ALT levels }<5 \times \text { ULN, } \\
\text { patient consent to not use } \\
\text { other investigational } \\
\text { drugs(agents) for Covid-19. }\end{array}$ & $\begin{array}{l}\text { missing post baseline } \\
\text { information, an incorrect } \\
\text { remdesivir start date }\end{array}$ & Severe & $\begin{array}{l}\text { DM in 9,HTN in } \\
13, \text { Asthma in 6,Any } \\
\text { coexisting condition } \\
\text { in } 36, \text { Hyperlipidemia } \\
\text { in } 6\end{array}$ & - & 13 \\
\hline $\begin{array}{l}\text { Cai et al. } \\
(21)\end{array}$ & China & 13-Apr-20 & $\begin{array}{l}\text { cross-sectional } \\
\text { study }\end{array}$ & 417 & $\begin{array}{l}198 \mathrm{M}, \\
219 \mathrm{~F}\end{array}$ & 49 & - & $\begin{array}{l}\text { Antibiotics, } \\
\text { NSAIDs, Ribavirin, } \\
\text { Oseltamivir, Herbal } \\
\text { medications, } \\
\text { Interferon, } \\
\text { lopinavir/ritonavir }\end{array}$ & $\begin{array}{l}\geq 1 \text { abnormal result of liver } \\
\text { test from admission until } \\
\text { end of February } 2020\end{array}$ & $\begin{array}{l}\text { patients with hypertension } \\
\text { at admission and found } \\
\text { that the prevalence of } \\
\text { abnormal liver function } \\
\text { tests remained similar }\end{array}$ & $\begin{array}{l}\text { severe } \\
\text { (91),mild } \\
\text { (326) }\end{array}$ & $\begin{array}{l}\text { DM in } 21, \mathrm{HTN} \text { in } \\
51 \text {,Prior hepatic } \\
\text { dysfunction in } 19\end{array}$ & $\begin{array}{l}\text { fever in } 248, \\
\text { cough in } 131\end{array}$ & - \\
\hline $\begin{array}{l}\text { Sun et al. } \\
\text { (22) }\end{array}$ & China & 20-Apr-2020 & $\begin{array}{l}\text { Retrospective } \\
\text { cohort study }\end{array}$ & 217 & $\begin{array}{l}106 \mathrm{M}, \\
111 \mathrm{~F}\end{array}$ & 45.7 & Chinese & $\begin{array}{l}\text { lopinavir/ritonavir, } \\
\text { umifenovir }\end{array}$ & $\begin{array}{l}\text { Confirmed SARS-CoV-2 } \\
\text { patients }\end{array}$ & - & Severe (50) & $\begin{array}{l}\text { In } 62 \text { patients (HTN, } \\
\text { DM, HIV, CVD, CKD, } \\
\text { COPD) }\end{array}$ & - & - \\
\hline $\begin{array}{l}\text { Wang } \\
\text { et al. (23) }\end{array}$ & China & 29-Apr-20 & $\begin{array}{l}\text { randomized } \\
\text { controlled trial }\end{array}$ & 158 & $89 \mathrm{M}, 69 \mathrm{~F}$ & $=66$ & - & remdesivir & $\begin{array}{l}\text { males and non-pregnant } \\
\text { females with COVID-19 } \\
\text { aged } \geq 18 \text { years with } \\
\text { positive RT-PCR test for } \\
\text { SARS-CoV-2, confirmed } \\
\text { pneumonia by chest } \\
\text { imaging, O2 Sat } \leq 94 \% \text { on } \\
\text { room air or a ratio of arterial } \\
\text { O2 partial pressure(PaO2) } \\
\text { to fractional inspired } \mathrm{O} 2 \leq \\
300 \mathrm{mmHg} \text {, within } 12 \text { days } \\
\text { of start of symptoms. }\end{array}$ & $\begin{array}{l}\text { pregnancy or breast } \\
\text { feeding; hepatic cirrhosis; } \\
\text { ALT or AST > } 5 \times \text { ULN; } \\
\text { known severe renal } \\
\text { impairment (estimated GFR } \\
<30 \mathrm{~mL} / \mathrm{min} \text { per } 1.73 \mathrm{~m}^{2} \text { ) } \\
\text { or receipt of continuous } \\
\text { renal replacement therapy, } \\
\text { haemodialysis, or } \\
\text { peritoneal dialysis; } \\
\text { possibility of transfer to a } \\
\text { non-study hospital within } \\
72 \mathrm{~h} \text {; enrolment into an } \\
\text { investigational treatment } \\
\text { study for COVID-19 within } \\
30 \text { days before screening }\end{array}$ & severe & $\begin{array}{l}\text { DM in } 40, \text { HTN in } 72, \\
\text { coronary heart } \\
\text { disease in } 15\end{array}$ & fever in 56 & $\begin{array}{l}\text { Day } 28 \text { clinical } \\
\text { improvement in } \\
103 \text { of } \\
\text { remdesivir } \\
\text { group and in } 45 \\
\text { of placebo } \\
\text { group - Clinical } \\
\text { improvement } \\
\text { rates at days } \\
14 \text { and day } 28 \\
\text { were also not } \\
\text { significantly } \\
\text { different } \\
\text { between the } \\
\text { groups, but } \\
\text { numerically } \\
\text { higher in the } \\
\text { remdesivir } \\
\text { group than the } \\
\text { placebo group }\end{array}$ \\
\hline
\end{tabular}


TABLE 1 | Continued

\begin{tabular}{|c|c|c|c|c|c|c|c|c|c|c|c|c|c|c|}
\hline $\begin{array}{l}\text { First } \\
\text { Author }\end{array}$ & Country & $\begin{array}{l}\text { Date of } \\
\text { publication }\end{array}$ & Type of study & $\begin{array}{l}\text { Sample } \\
\text { size }\end{array}$ & $\begin{array}{l}\text { Male: } \\
\text { Female }\end{array}$ & $\begin{array}{c}\text { Mean } \\
\text { age }\end{array}$ & Nationality & MEDICATIONS & Inclusion criteria & Exclusion criteria & $\begin{array}{l}\text { Severity of } \\
\text { disease } \\
\text { (mild, mod, } \\
\text { severe) }\end{array}$ & Complications & $\begin{array}{l}\text { COVID-19 } \\
\text { symptoms }\end{array}$ & Discharge \\
\hline $\begin{array}{l}\text { Antinori } \\
\text { et al. (24) }\end{array}$ & Italy & 11-May-20 & $\begin{array}{l}\text { prospective } \\
\text { (compassionate), } \\
\text { open-label } \\
\text { study }\end{array}$ & 35 & $\begin{array}{c}26 \mathrm{M} \\
9 \mathrm{~F}\end{array}$ & 63 & Italian & remdesivir & $\begin{array}{l}\text { males or non-pregnant } \\
\text { females aged }>18 \text { years, } \\
\text { with SARS-CoV-2 infection } \\
\text { confirmed by RT-PCR of a } \\
\text { respiratory tract sample } \\
\text { and pneumonia confirmed } \\
\text { by a chest X-ray or CT } \\
\text { scan, mechanically } \\
\text { ventilated or SaO2 level of } \\
<94 \% \text { in room air or a } \\
\text { National Early Warning } \\
\text { Score (NEWS) } 2 \\
\text { of } \geq 4\end{array}$ & $\begin{array}{l}\text { ALT or AST level }>5 x \text { ULN, } \\
\text { creatinine clearance }<30 \\
\mathrm{~mL} / \mathrm{min}\end{array}$ & - & $\begin{array}{l}\text { DM in } 3, \text { HTN in } 12, \\
\text { obesity in } 3, \text { cancer in } \\
1\end{array}$ & - & $\begin{array}{l}\text { At day } 28 \text { from } \\
\text { starting } \\
\text { remdesivir, } 14 \\
\text { patients were } \\
\text { discharged } \\
\text { from IDW, from } \\
\text { ICU } 6 \\
\text { discharged, } 1 \\
\text { was improved } \\
\text { but still } \\
\text { hospitalized }\end{array}$ \\
\hline $\begin{array}{l}\text { Mangoni } \\
\text { et al. (25) }\end{array}$ & Italy & 16-May-20 & case Report & 4 & $4 M$ & 52 & Italian & remdesivir & - & - & severe & - & $\begin{array}{l}\text { severe } \\
\text { pneumonia } \\
\text { and respiratory } \\
\text { distress }\end{array}$ & 3 \\
\hline $\begin{array}{l}\text { Muhović } \\
\text { et al. (26) }\end{array}$ & Montenegro & 17-May-20 & case report & 1 & $1 \mathrm{M}$ & 52 & Montenegrin & Tocilizomab & - & - & severe & - & fever, cough & - \\
\hline $\begin{array}{l}\text { Goldman } \\
\text { et al. (27) }\end{array}$ & US & 27-May-20 & $\begin{array}{l}\text { multicenter, } \\
\text { randomized, } \\
\text { open-label, } \\
\text { phase } 3 \text { trial }\end{array}$ & 397 & $\begin{array}{l}253 \mathrm{M}, \\
144 \mathrm{~F}\end{array}$ & 61.5 & $\begin{array}{l}\text { United States, } \\
\text { Italy, Spain, } \\
\text { Germany, Hong } \\
\text { Kong, Singapore, } \\
\text { South Korea, } \\
\text { Taiwan }\end{array}$ & remdesivir & $\begin{array}{l}\text { confirmed SARS-CoV-2 } \\
\text { infection, age } \geq 12 \text { years, } \\
\text { O2 Sat } \leq 94 \% \text { while } \\
\text { breathing ambient air or O2 } \\
\text { support, radiologic } \\
\text { evidence of pneumonia }\end{array}$ & $\begin{array}{l}\text { mechanical ventilation or } \\
\text { extracorporeal membrane } \\
\text { oxygenation (ECMO) at } \\
\text { screening, ALT or AST > } 5 x \\
\text { ULN, creatinine clearance } \\
<50 \mathrm{~mL} / \mathrm{min} \text {, receiving } \\
\text { simultaneous treatment } \\
\text { (within } 24 \mathrm{~h} \text { before the start } \\
\text { of trial treatment) with other } \\
\text { agents with supposed } \\
\text { activity } \\
\text { against Covid-19 }\end{array}$ & severe & $\begin{array}{l}\text { DM in } 90, \text { HTN in } \\
198, \text { asthma in } 49, \\
\text { hyperlipidemia in } 89\end{array}$ & - & 84 \\
\hline $\begin{array}{l}\text { Falcão } \\
\text { et al. (28) }\end{array}$ & Brazil & 1-Jun-20 & case report & 1 & $1 \mathrm{~F}$ & 29 & Brazilian & $\mathrm{HCQ}$ & - & - & severe & - & $\begin{array}{l}\text { dry cough, } \\
\text { severe } \\
\text { dyspnea, } \\
\text { weakness, one } \\
\text { episode of } \\
\text { hemoptysis }\end{array}$ & - \\
\hline $\begin{array}{l}\text { Jiang } \\
\text { et al. (29) }\end{array}$ & China & 23-Jun-20 & $\begin{array}{l}\text { Multicenter } \\
\text { retrospective, } \\
\text { observational } \\
\text { study }\end{array}$ & 131 & $\begin{array}{l}70 \mathrm{M}, \\
61 \mathrm{~F}\end{array}$ & $\begin{array}{r}51.21 \pm \\
6.1\end{array}$ & Chinese & lopinavir/ritonavir & $\begin{array}{l}\text { critically ill and non-critically } \\
\text { ill }\end{array}$ & $\begin{array}{l}\text { pregnancy, }<18 \text { years old, } \\
\text { liver function abnormality } \\
\text { before treatment }\end{array}$ & $\begin{array}{l}\text { non-severe } \\
=\text { mild or } \\
\text { moderate } \\
\text { (30), severe } \\
\text { (22) critically } \\
\text { ill (27) }\end{array}$ & $\begin{array}{l}\text { Cardiovascular and } \\
\text { cerebrovascular } \\
\text { diseases in } 37, \\
\text { endocrine system } \\
\text { disease in } \\
22, \text { Digestive system } \\
\text { disease in } 5, \\
\text { Neurological } \\
\text { disorders in } 4, \\
\text { Immune system } \\
\text { in } 2\end{array}$ & - & - \\
\hline
\end{tabular}


TABLE 1 | Continued

\begin{tabular}{|c|c|c|c|c|c|c|c|c|c|c|c|c|c|c|}
\hline $\begin{array}{l}\text { First } \\
\text { Author }\end{array}$ & Country & $\begin{array}{l}\text { Date of } \\
\text { publication }\end{array}$ & Type of study & $\begin{array}{l}\text { Sample } \\
\text { size }\end{array}$ & $\begin{array}{l}\text { Male: } \\
\text { Female }\end{array}$ & $\begin{array}{c}\text { Mean } \\
\text { age }\end{array}$ & Nationality & MEDICATIONS & Inclusion criteria & Exclusion criteria & $\begin{array}{l}\text { Severity of } \\
\text { disease } \\
\text { (mild, mod, } \\
\text { severe) }\end{array}$ & Complications & $\begin{array}{l}\text { COVID-19 } \\
\text { symptoms }\end{array}$ & Discharge \\
\hline $\begin{array}{l}\text { Guaraldi } \\
\text { et al. (31) }\end{array}$ & Italy & 24-Jun-2020 & $\begin{array}{l}\text { retrospective, } \\
\text { observational } \\
\text { cohort study }\end{array}$ & 179 & $\begin{array}{l}127 \mathrm{M} \\
52 \mathrm{~F}\end{array}$ & 64 & - & tocilizumab & $\begin{array}{l}\geq 18 \text { years with } \mathrm{PCR} \\
\text { confirmed COVID-19 on } \\
\text { nasopharyngeal swab, } \\
\text { eligible for tocilizumab } \\
\text { treatment, if presented } \\
\mathrm{SaO} 2<93 \% \text { and a } \\
\mathrm{PaO} 2 / \mathrm{FiO} 2 \text { ratio }<300 \mathrm{~mm} \\
\mathrm{Hg} \text { in room air or a decline } \\
>30 \% \text { in them } \\
\mathrm{PaO} 2 / \mathrm{FiO} 2 \text { ratio in the last } \\
24 \mathrm{~h} \text { during hospitalization. }\end{array}$ & $\begin{array}{l}\text { Exclusion criteria for } \\
\text { tocilizumab use: } \\
\text { concurrent infection other } \\
\text { than COVID-19; a } \\
\text { PaO2/FiO2 ratio }>300 \mathrm{~mm} \\
\mathrm{Hg} \text {; chronic or current use } \\
\text { of glucocorticoid; history of } \\
\text { severe allergic reactions to } \\
\text { monoclonal antibodies; < } \\
500 \text { per } \mu \mathrm{L} \text { neutrophils or } \\
<50 \times 10^{9} \text { platelets; } \\
\text { active diverticulitis, } \\
\text { inflammatory bowel } \\
\text { disease, or another } \\
\text { symptomatic digestive tract } \\
\text { condition that might incline } \\
\text { patients to perforation of } \\
\text { bowel; severe liver, renal, or } \\
\text { hematological function } \\
\text { damage. }\end{array}$ & - & $\begin{array}{l}\text { cancer in 2, renal } \\
\text { insufficieiency in } 2\end{array}$ & - & - \\
\hline $\begin{array}{l}\text { Leegwater } \\
\text { et al. (32) }\end{array}$ & $\begin{array}{l}\text { The } \\
\text { Netherlands }\end{array}$ & 28-Jun-20 & case report & 1 & $1 \mathrm{M}$ & 64 & $\begin{array}{l}\text { Dutch (the } \\
\text { Netherlands) }\end{array}$ & remdesivir & - & - & severe & $\begin{array}{l}\text { HTN, } \\
\text { hypercholesterolemia }\end{array}$ & $\begin{array}{l}\text { Fever, cough, } \\
\text { headache, } \\
\text { progressive } \\
\text { dyspnea }\end{array}$ & 1 \\
\hline $\begin{array}{l}\text { Dubert } \\
\text { et al. (33) }\end{array}$ & France & 30-Jun-20 & case series & 5 & $5 \mathrm{M}$ & 59.2 & Chinese, French & remdesivir & $\begin{array}{l}\text { patients admitted to the } \\
\text { Bichat-Claude Bernard } \\
\text { University Hospital, Paris, } \\
\text { France, between January } \\
24 \text { and March } 1,2020, \\
\text { diagnosed with COVID-19 } \\
\text { and treated with remdesivir } \\
\text { (GileadSciences), criteria } \\
\text { for compassionate-use } \\
\text { remdesivir defined by the } \\
\text { French national regulatory } \\
\text { authorities and French } \\
\text { Ministry of Health: signs of } \\
\text { severe illness at diagnosis } \\
\text { or subsequent clinical } \\
\text { worsening (respiratory } \\
\text { symptoms or general signs) }\end{array}$ & - & $\mathrm{ICU}$ & $\begin{array}{l}\text { Obesity in } 1 \text {, } \\
\text { malignancy in } 1 \text {, } \\
\text { pulmonary disease in } \\
1 \text {, chronic kidney } \\
\text { injury in } 1\end{array}$ & $\begin{array}{l}\text { fever in } 5 \text {, } \\
\text { cough in } 4 \text {, Gl } \\
\text { symptoms in } 1\end{array}$ & 3 \\
\hline $\begin{array}{l}\text { Kelly et al. } \\
\text { (34) }\end{array}$ & Ireland & 8-Jul-20 & $\begin{array}{l}\text { retrospective } \\
\text { study }\end{array}$ & 82 & $\begin{array}{l}55 \mathrm{M} \\
27 \mathrm{~F}\end{array}$ & 64.8 & - & $\begin{array}{l}\text { HCQ+ } \\
\text { azithromycin }\end{array}$ & - & - & - & - & - & - \\
\hline $\begin{array}{l}\text { Lee et al. } \\
\text { (35) }\end{array}$ & Korea & 23-Jul-20 & $\begin{array}{l}\text { retrospective } \\
\text { case series }\end{array}$ & 10 & $5 \mathrm{M}, 5 \mathrm{~F}$ & 52 & $\begin{array}{l}\text { Korean (ME: } \\
\text { Korea, } \\
\text { Philippines, UK) }\end{array}$ & remdesivir & $\begin{array}{l}\text { confirmed diagnosis of } \\
\text { SARS-CoV-2-related } \\
\text { pneumonia, aged } \geq 18 \\
\text { years (or } 12-18 \text { years if } \\
\text { weighed } \geq 40 \mathrm{~kg} \text { ) and } \mathrm{O} 2 \\
\text { Sat of } \leq 94 \% \text { in room air }\end{array}$ & $\begin{array}{l}\text { evidence of multi-organ } \\
\text { failure, mechanical } \\
\text { ventilation }>5 \text { days, serum } \\
\text { AST or ALT }>5 x \text { ULN, } \\
\text { creatinine clearance }<50 \\
\mathrm{~mL} / \text { min (Cockcroft-Gault } \\
\text { formula if aged } \geq 18 \text { years } \\
\text { and Schwartz formula in } \\
\text { aged }<18 \text { years), }\end{array}$ & 3 in ICU & $\begin{array}{l}\text { HTN in } 3, \mathrm{FLD} \text { in } 1, \\
\text { other comorbidities in } \\
2\end{array}$ & $\begin{array}{l}\text { fever in } 8 \text {, } \\
\text { cough in } 5 \text {, } \\
\text { asymptomatic } \\
\text { in } 1 \text {, other } \\
\text { symptoms in } \\
10\end{array}$ & 3 \\
\hline
\end{tabular}


TABLE 1 | Continued

\begin{tabular}{|c|c|c|c|c|c|c|c|c|c|c|c|c|c|c|}
\hline $\begin{array}{l}\text { First } \\
\text { Author }\end{array}$ & Country & $\begin{array}{l}\text { Date of } \\
\text { publication }\end{array}$ & Type of study & $\begin{array}{l}\text { Sample } \\
\text { size }\end{array}$ & $\begin{array}{l}\text { Male: } \\
\text { Female }\end{array}$ & $\begin{array}{c}\text { Mean } \\
\text { age }\end{array}$ & Nationality & MEDICATIONS & Inclusion criteria & Exclusion criteria & $\begin{array}{l}\text { Severity of } \\
\text { disease } \\
\text { (mild, mod, } \\
\text { severe) }\end{array}$ & Complications & $\begin{array}{l}\text { COVID-19 } \\
\text { symptoms }\end{array}$ & Discharge \\
\hline
\end{tabular}

severe)

\begin{tabular}{|c|c|c|c|c|c|c|c|c|c|c|c|c|c|c|}
\hline & & & & & & & & & & $\begin{array}{l}\text { pregnancy or } \\
\text { breastfeeding, known } \\
\text { hypersensitivity to RDV or } \\
\text { its metabolites, } \\
\text { participation in another } \\
\text { clinical trial }\end{array}$ & & & & \\
\hline $\begin{array}{l}\text { Zampino } \\
\text { et al. (36) }\end{array}$ & Italy & 28-Jul-20 & case series & 5 & $5 \mathrm{M}$ & 51.2 & Italian & remdesivir & $\begin{array}{l}\text { invasive mechanical } \\
\text { ventilation, ALT }<5 x \text { ULN, } \\
\text { creatinine clearance }>30 \\
\mathrm{~mL} / \mathrm{min}\end{array}$ & $\begin{array}{l}\text { Multi-organ failure, a need } \\
\text { for vasopressor }\end{array}$ & - & HTN in 1 , asthma in 1 . & & $\begin{array}{l}\text { Final outcome } \\
\text { positive in } 4 / 5 \\
\text { patients (maybe } \\
4 \text { discharged) }\end{array}$ \\
\hline $\begin{array}{l}\text { Hundt } \\
\text { et al. (37) }\end{array}$ & USA & 29-July-2020 & $\begin{array}{l}\text { Retrospective } \\
\text { observational } \\
\text { cohort }\end{array}$ & 1,827 & $\begin{array}{l}969 \mathrm{M}, \\
858 \mathrm{~F}\end{array}$ & 64.6 & - & $\begin{array}{l}\text { lopinavir/ritonavir ( } n \\
=136) \text {, } \\
\text { hydroxychloroquine } \\
(n=1,469), \\
\text { remdesivir }(n=46) \text {, } \\
\text { and tocilizumab ( } n \\
=772)\end{array}$ & $\begin{array}{l}\text { patients who tested } \\
\text { positive for SARS-CoV-2 } \\
\text { by PCR of nasopharyngeal } \\
\text { swab }\end{array}$ & - & $\begin{array}{l}\text { Non-severe } \\
(n=1,175) \\
\text { Severe }(n= \\
652)\end{array}$ & $\begin{array}{l}\text { DM in } 712 \text {, Obesity in } \\
748\end{array}$ & & - \\
\hline $\begin{array}{l}\text { Carothers } \\
\text { et al. (38) }\end{array}$ & US & 2-Oct-20 & case series & 2 & $2 \mathrm{~F}$ & 74 & - & remdesivir & - & - & - & $\begin{array}{l}\text { DM in 2, HTN in 2, } \\
\text { CAD in } 1, \\
\text { hyperlipidemia in } 2\end{array}$ & $\begin{array}{l}\text { fever in } 1 \text {, } \\
\text { oxygen } \\
\text { saturation in } \\
\text { the } 70 \text { s and } \\
82 \mathrm{~s} \text { s systolic } \\
\text { blood pressure } \\
>200 \mathrm{~mm} \mathrm{Hg} \\
\text { in } 1 \text {, chills in } 2 \text {, } \\
\text { fatigue in } 2 \text {, } \\
\text { body aches in } \\
1, \text { low back } \\
\text { pain in } 1, \\
\text { shortness of } \\
\text { breath in } 1 \text {, } \\
\text { difficulty with } \\
\text { urination in } 1\end{array}$ & 1 \\
\hline $\begin{array}{l}\text { Serviddio } \\
\text { et al. (39) }\end{array}$ & Italy & 7-Oct-20 & case series & 7 & $7 \mathrm{M}$ & 59 & - & $\begin{array}{l}\mathrm{HCQ}+ \\
\text { azithromycin+ } \\
\text { lopinavir/ritonavir }\end{array}$ & - & - & $\begin{array}{l}\text { mild (6), } \\
\text { severe (2) }\end{array}$ & - & fever in 7 & 7 \\
\hline $\begin{array}{l}\text { Aiswarya } \\
\text { et al. (40) }\end{array}$ & India & 18-Dec-2020 & $\begin{array}{l}\text { Observational } \\
\text { prospective } \\
\text { study }\end{array}$ & 48 & $\begin{array}{l}38 \mathrm{M} \\
10 \mathrm{~F}\end{array}$ & 50 & - & remdesivir & $\begin{array}{l}\text { patients with CKD needing } \\
\text { hemodialysis, who had } \\
\text { positive test for } \\
\text { SARS-CoV-2 infection from } \\
\text { nasopharyngeal swab by } \\
\text { RT-PCR with moderate or } \\
\text { severe infection, and who } \\
\text { received } \geq 1 \text { dose of } \\
\text { remdesivir }\end{array}$ & $\begin{array}{l}\text { Patients with mild } \\
\text { disease and underlying } \\
\text { chronic hepatic disease }\end{array}$ & $\begin{array}{l}\text { Moderate } \\
\text { (21), severe } \\
\text { (27) }\end{array}$ & $\begin{array}{l}\text { DM in } 20, H T N \text { in } 41, \\
\text { all patients }(n=48), \\
\text { CKD in all patients. }\end{array}$ & - & 38 \\
\hline $\begin{array}{l}\text { Yamazaki } \\
\text { et al. (41) }\end{array}$ & Japan & 28-Dec-2020 & Case report & 1 & $1 \mathrm{M}$ & 73 & Japanese & favipiravir & - & - & severe & $\begin{array}{l}\text { Alcoholic hepatitis, } \\
\text { HTN, hyperlipidemia, } \\
\text { gastric ulcer, BPH, } \\
\text { anemia }\end{array}$ & - & - \\
\hline
\end{tabular}

HTN, hypertension; CKD, chronic kidney disease; BPH, benign prostatic hyperplasia; FLD, fatty liver disease; DM, diabetes mellitus; CAD, coronary artery disease; CVD, cardiovascular disease; COPD, chronic obstructive pulmonary disease. 


\section{-Lopinavir/Ritonavir}

A significant number of studies have reported the association of lopinavir/ritonavir to use in COVID-19 patients with adverse liver effects. In a study by Sun et al. on a sample of 217 patients, $63 \%$ of total adverse drug reactions (ADRs) were associated with the use of lopinavir/ritonavir, whereas the use of other drugs including umifenovir, chloroquine, and antibacterial drugs together accounted for the additional $47 \%$ of ADRs. Liver ADRs were the second common ADRs by a prevalence of $18 \%$. However, the percentage of liver ADRs due to lopinavir/ritonavir was not reported by the same study (22). Later, Fan et al. reported that among the 148 patients, 45 patients had normal base-line liver functions of which, $48 \%$ developed an abnormality in the liver after admission to the hospital. They highlighted that among the patients with abnormal liver functions, a higher proportion had used lopinavir/ritonavir $(57.8 \%)$ compared to the patients with normal liver function tests (31.3\%) (17).

Furthermore, Cia et al. reported that liver dysfunction was significantly higher in lopinavir/ritonavir treated group in a study with 417 COVID-19 patients. A 4-fold magnitude increased liver function odds, and the most common increase in test results was observed in gamma-glutamyl transferase and total bilirubin. Yet, due to the lack of evidence supporting the role of drugs in observed liver injury, the definition of DILI by clinical guidelines from the "European Association for the Study of the Liver" was not applicable for this study (21). In another line of studies, Jiang et al. observed that adding each concomitant medication is followed by a $12.1 \%$ increase in odds of liver function (29). In addition, concomitant use of lopinavir/ritonavir and arbidol in non-critically ill COVID19 patients increased the odds of liver functions more than expected, to 3.58 times greater who didn't receive the medications mentioned earlier. To find out the mechanism of this abnormal increase, metabolic interactions between the two medications were explored using human liver microsomes. In the following line of evidence, a case series of seven patients who showed significant abnormal liver tests in addition to worsening of the respiratory system function 5-7 days following the treatment with lopinavir/ritonavir, hydroxychloroquine, and azithromycin, use of tocilizumab was seen to relieve both lung and liver functions within 3 weeks (39).

\section{-Tocilizumab}

A retrospective study reported no adverse liver effects on 1,351 patients treated with tocilizumab conducted by Guaraldi et al. (31). However, there is a case report DILI following the use of tocilizumab, which was suggested to possibly be a result of previous use of lopinavir/ritonavir (26). Another study conducted by Hundt et al. reported a significant correlation between the use of lopinavir/ritonavir, hydroxychloroquine, remdesivir, and tocilizumab developing a liver injury. Furthermore, the strongest correlation was related to the use of tocilizumab (37).

\section{-Hydroxychloroquine (+/-Azithromycin)}

A retrospective analysis on a sample of 134 patients reported that the liver function tests were not significantly different between patients treated with hydroxychloroquine/azithromycin compared to the patients who didn't receive targeted therapies (34). However, Falcao et al. reported a severe COVID-19 case of hepatotoxicity (28) related to hydroxychloroquine. The patient showed a 10 -fold increase in levels of transaminases in serum, which rapidly decreased after being withdrawn from hydroxychloroquine.

\section{-Favipiravir}

We found one study reporting the effect of favipiravir use on liver function. This case report described a patient who developed cholestatic liver injury caused by favipiravir. However, based on the author's view, the administration of antibacterial treatment triggered the liver injury, and a high dose of favipiravir worsened the liver function (41).

Table 2 provides a brief overview of the effects of the mentioned medications on the liver function tests.

\section{DISCUSSION}

Among included studies, some of theme revealed a direct role of drugs, while others couldn't certainly confirm that the liver injury was due to SARS-CoV-2 itself or administration of medications. However, a major number of studies reported that liver injury could be attributable to drug administration. Among included studies, one study reported that liver-related adverse effects were not significantly different between patients who used hydroxychloroquine (HCQ) and azithromycin and the control group (34). Another study, however, reported that DILI in COVID-19 is mainly attributed to the type of the drug. For instance, a study conducted in China by Cai et al. reported that drugs such as antibiotics, NSAIDs, ribavirin, herbal medication, and interferon did not significantly lead to a higher risk of liver injury. In contrast, drugs including lopinavir/ritonavir were associated with $4 \times$ higher odds of liver injury (21). Of course it is noteworthy to imply that the efficacy of lopinavir/ritonavir in COVID-19 patients is still under question and should be evaluated in further studies $(42,43)$.

Furthermore, Chinese herbal medication and antibiotics are frequently related to DILI in China, but Chinese herbal medicine was not associated with liver injury (44). Therefore, it can be concluded that there is no consensus on what drugs could lead to DILI, particularly in the COVID-19 context. According to included studies, all papers that evaluated the adverse effects of remdesivir on the liver reported that remdesivir could lead to liver injury except for one recent article which demonstrated that RDV treatment was not associated with transaminase elevation (40). The most controversial reports of DILI were about the effect of tocilizumab on the liver. One study reported that tocilizumab improved liver adverse effects caused by the administration of lopinavir/ritonavir (39). Inconsistently, a study conducted by Muhovic et al. reported the first case of DILI caused by tocilizumab. According to this study, previous use of antiviral drugs such as lopinavir/ritonavir could increase the hepatotoxic effects of tocilizumab (26). Moreover, a retrospective cohort study conducted by Guaraldi et al. has demonstrated that tocilizumab does not increase transaminases in COVID-19 patients (31). 
TABLE 2 | Effect of drugs on liver function tests.

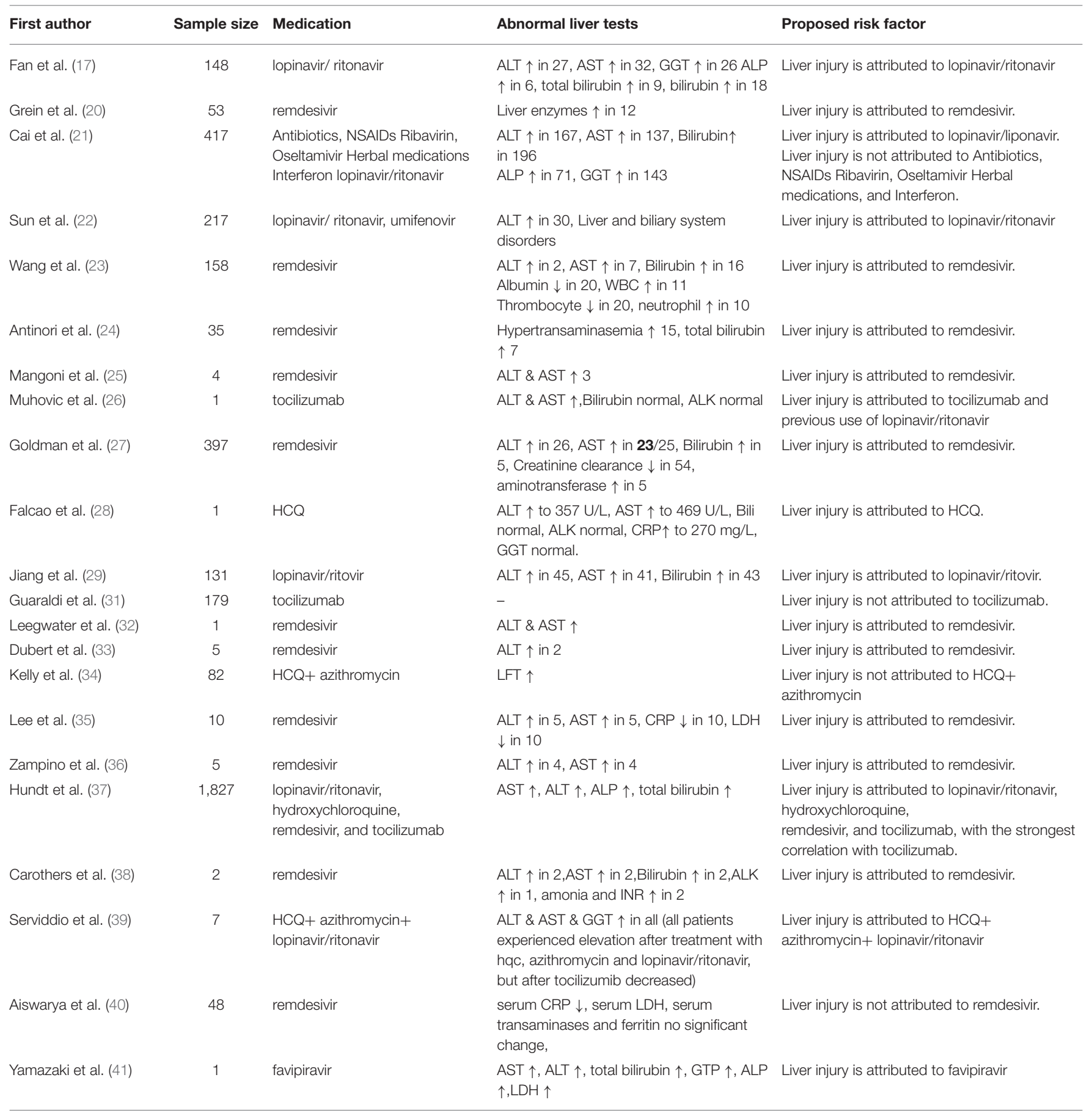

ALT, alanine aminotransferase; AST, aspartate aminotransferase; ALP/ALK, alkaline phosphatase; ALK, alkaline; GGT, gamma-glutamyl transferase; GTP, gama-glutamyl transpeptidase; $L D H$, lactate dehydrogenase; CRP, C-reactive protein.

Two meta- analysis studies, although incoherent about the efficacy of tocilizumab, have concluded that tocilizumab is not associated with liver injury in COVID-19 patients $(45,46)$. Also it has been reported that a combination of tocilizumab with other hepatotoxic agents could lead to severe liver injury (26). Developing DILI in patients is associated with various factors. For instance, Falcao et al. reported that a high dose of recommended HCQ could increase the risk of hepatotoxicity in COVID-19 patients. Moreover, certain medical conditions such as porphyria cutanea tarda, viral hepatitis, and rheumatologic diseases could enhance the risk of liver injury development (28). Further, there is a drug-drug interaction with chloroquine and its derivatives 
with anti-rejection immunosuppressant (47). Based on a metaanalysis, the incidence of DILI in a population of 208 patients treated with remdesivir was $15.2 \%$, while the incidence of DILI among 775 patients treated with lopinavir/ritonavir was $37.2 \%$ (5). According to a meta-analysis conducted by Yadav et al., severe cases and patients with liver injury are at higher risk of mortality therefore, during treatment, they should be given special and careful attention (48).

\section{Liver Involvement in COVID-19 Infection}

SARS-COV-2 enters the host cells through the angiotensin 2 conversion enzyme (ACE2) receptor. This receptor is expressed in various tissues, including lungs, the heart, and the liver. ACE2 receptor in the liver is highly expressed in cholangiocytes $(60 \%)$ and hepatocytes (3\%), indicating that the liver could be a potential target for SARS-CoV-2 invasion (49).

Liver involvement during COVID-19 infection is associated with various factors. Several mechanisms have been postulated about liver involvement in COVID-19 infection that can be listed as: (1) direct invasion of the virus to liver cells through ACE2 receptor, (2) uncontrolled inflammatory responses that lead to fibrosis and liver dysfunction, (3) liver dysfunction caused by administration of anti-COVID-19 drugs, (4) hypoxia and cardiac failure in severe COVID-19 patients could contribute to the development of liver injury (50).

\section{Drug-Induced Liver Injury}

Drug-induced liver injury (DILI) is liver lesion/dysfunction caused by medication. The incidence of DILI is low; however, it could lead to acute liver failure and urgent liver transplantation. In patients with acute liver failure, DILI is a differential diagnosis (49). To better diagnose DILI in suspected patients, the potential hepatotoxic effect of drugs and various influential factors including race, age, and sex should be considered (51). In patients with COVID-19, the cause of liver dysfunction should be determined. Furthermore, taking appropriate measures such as ALT, AST, total bilirubin, direct bilirubin, albumin, and INR monitoring could significantly reduce morbidity and mortality. Moreover, patients with DILI should be given anti-inflammatory liver protection medication, and special attention should be considered to alter the dosage or discontinue the suspected drugs (49). In patients with severe COVID-19 infection and patients with pre-existing liver diseases, too many drugs (more than 2) with the potential of hepatotoxic effect should not be given. Drugs in patients with ongoing anti-HBV and anti-HCV should not be discontinued; but instead, they should be carefully monitored (49).

Definition of acute liver injury is based on the ULN of serum concentration of ALT, AST, and total bilirubin. It is as follows: 1 increase level of ALT $\geq 5$-times ULN, or increase level of ALP $\geq 2$ times ULN (in the absence of bone pathology), or simultaneous increase of ALT $\geq 3$-times ULN and total bilirubin concentration $>2$-times ULN (52).

It has been reported that patients who developed favipiravir (FRP)-induced liver damage had higher FRP serum levels than patients who did not (53). Practitioners should notice a large variation in FRP concentration between patients; therefore, monitoring FPR concentration in patients' blood and personalized FPR dosing could be helpful. Administration of FRP could cause the enhanced level of ALT, AST, ALP, and total bilirubin. In the context of COVID-19 infection, ALT elevation with the use of FPR occurs in $<10 \%$ of patients (54). It should be considered that in patients with severe COVID-19 infection reduced dosage of FPR should be administered (55). A review on the safety and efficacy of FRP in COVID-19 patients revealed that there is not a significant difference in LFT changes in the FRP group compared to the comparison group (56). Consistently, a recent meta-analysis study reported FRP leads to non-significantly lower odds for adverse effects compared to placebo (57).

Studies have reported that administration of RDV is associated with AST and ALT elevation (36). Consistently, according to our included studies, the most important changes of liver enzymes were altered levels of ALT and ST. However, in most cases, elevated levels of AST and ALT do not progress to severe liver injury (58). Based on reports, liver injury caused by RDV occurred in two patients manifested with increased transaminases, coagulopathy, and hepatic encephalopathy that occurred between days 3 and 10 of RDV administration. Practitioners used $\mathrm{N}$-acetyl cysteine and discontinued RDV to stop the progression of acute liver failure (38). It should be considered that in the following conditions RDV should be stopped; ALT >5-times ULN or ALP > 2-times ULN, and total bilirubin $>2$-times ULN or presence of coagulopathy or clinical decompensation (54). To reduce RDV-induced liver adverse effects, liver function tests should be performed and analyzed before drug initiation. Moreover, physicians should monitor the liver function tests during treatment with RDV (59). Carothers et al. have suggested that the use of acetylcysteine can be beneficial in the management of acute liver failure (ALF) induced by remdesivir (38). Acetylcysteine is an antidote to acetaminophen, the leading cause of ALF, which is possibly useful also for ALF caused by drugs other than acetaminophen (60).

Azithromycin could cause idiosyncratic acute liver damage. azithromycin-induced liver injury manifested with cholestatic hepatitis occurring 1-3 weeks after treatment initiation. Moreover, hepatocellular injury associated with azithromycin has a short latency (52). azithromycin is also known to develop cutaneous reactions, including erythema multiform and StevensJohnson syndrome, that are often associated with a degree of liver involvement (61).

Moderate to severe elevation in serum concentration of aminotransferases (>5-times UNL) could be seen in 3-10\% of patients who have used lopinavir. The extent of liver injury varies from hepatocellular injury to cholestatic injury or both (62). Elevation of liver enzymes following the use of ritonavir is rare and self-limited. Moreover, the administration of lopinavir/ritonavir could exacerbate liver dysfunction in patients with HBV and HCV infection (52).

We did not include ivermectin (IVN) and colchicine into our search strategy but as there is a tendency to investigate the possible usefulness of these two medications in COVID19 treatment, we should point them. IVN, a well-known antiparasite medication, is considered a safe drug, and reports 
on its hepatotoxic effects are rare. There are growing and controversial evidences about IVN efficacy in treatment of COVID-19 patients but it seems to be a safe medication in overall (63-66). Of course there is a case report of IVN caused DILI (elevated aminotransferase, acute hepatocellular necrosis, lobular infiltration of lymphocytes, and without fibrosis) 1 month after drug administration and the patient clinically improved after 3 months (67). Colchicine is also another well-known drug used as an anti-inflammatory agent in wide range of diseases that has also been reported to reduce the severity, hospitalization period, and the mortality of COVID-19 and prevention of cytokine storm (68-71). But excessive cautions should be take place in colchicine dosage as it is easily affected by many factors $(72,73)$. Currently there are not enough data to comment on the effects of colchicine on the liver function of COVID-19 patients and further studies are recommended to elucidate it.

Practitioners could better diagnose the DILI in suspected patients based on Roussel Uclaf Causality Assessment Method (RUCAM). RUCAM is a structured, standardized, and validated method for the assessment of DILI. However, a major number of related studies did not use RUCAM to evaluate the liver damage and assess the risk of DILI, causing confounding results in the diagnosis of DILI in COVID-19 patients. Therefore, RUCAM could provide an accurate quantitative casualty grading for suspected drugs and verify DILI in suspected patients (30).

\section{Mechanisms of Drug-Induced Liver Injury}

The mechanisms underlying liver injury in COVID-19 patients are not yet fully understood; however, drug-induced liver injury has been significantly cited in the literature among various causes of liver damage in COVID-19.

$\mathrm{Xu}$ et al. have reported moderate micro vesicular steatosis in post-mortem liver tissue of a COVID-19 patient (74), a condition in which hepatocytes are filled with fat vesicles due to either viral- or drug-induced injury. Drug-induced steatosis is mainly caused by drug interference with $\beta$-oxidation of fatty acids, mitochondrial respiration, or both (75), resulting in the accumulation of non-esterified fatty acids which are subsequently converted into triglycerides (76).

Several mechanisms are known to sensitize hepatocytes to SARS-CoV-2 infection or therapeutic chemicals. Underlying diseases including diabetes type 1 or 2 and hypertension, would enhance direct SARS-CoV-2 hepatotoxicity due to upregulation of ACE2 following the use of angiotensin receptor blockers or ACE inhibitor drugs $(77,78)$. Non-alcoholic fatty liver disease (NAFLD), which can be resulted from diabetes itself, sensitizes hepatocytes to therapeutic chemicals, specifically antipyretic drugs containing acetaminophen $(79,80)$.

The other mechanism thought to affect hepatocytes is downregulation of cytochromes p450 or CYPs family; enzymes involved in oxidative biotransformation of many drugs including the ones used in COVID-19 management. This downregulation is thought to be caused by the elevation of cytokines and interleukins especially IL-6, which is a major inflammatory mediator exerting repressive effects on several CYPs, as a result of cytokine storm syndrome (CSS) in COVID-19. Possible CYPs downregulation can affect the metabolism of several COVID19 drugs, specifically remdesivir, the metabolism of which is extensively relied on CYPs. It's also thought that consuming multiple drugs would add up metabolic complexity to this situation (81).

As an example, arbidol and lopinavir are metabolized by Cytochrome P3A (CYP3A) which can be inhibited by ritonavir, hence using arbidol with lopinavir/ritonavir (LPV/RTV) at the same time may result in liver injury. It is concluded that the interaction between arbidol and lopinavir/ritonavir, elevates the serum concentration of arbidol and lopinavir and increases the risk of liver damage (29). Ribavirin causes hemolysis which in turn can aggravate or induce tissue hypoxia; this condition may lead to elevated levels of liver enzymes in the serum (82).

Almost all of the drugs prescribed for COVID-19, such as oseltamivir, lopinavir/ritonavir, ribavirin, chloroquine phosphate, and hydroxyl chloroquine sulfate are metabolized in the liver, hence liver damage and elevation of liver enzymes following the treatment is predictable (83). Pharmacological features of anti-COVID-19 drugs might elevate the risk of liver damage; lipophilicity, liability in the mitochondria, generation of reactive metabolites, the metabolism pathway in the liver, and the ability to inhibit hepatic transporters are some of the critical features that can lead to hepatotoxicity in susceptible hosts (84).

In a previous study by Griffin et al., 10-min exposure of rat hepatocytes to LPV and RTV, two protease inhibitor (PI) drugs, caused intracellular accumulation of Taurocholic Acid (TCA), suggesting that hepatotoxicity induced by PIs may be a result of their interference with the efflux of bile acids from hepatocytes (85). In addition, a series of studies have reported LPV as an important inhibitor of multidrug resistance-associated protein 2 (MRP2), an apical efflux transporter in hepatocytes, contributing to the excretion of bile acids $(86,87)$. In a more recent study evaluating the biliary excretion index (BEI) of 5(6)-carboxy-29, 79 dichlorofluorescein (CDF) through confocal imaging, the inhibitory effects of LPV was further supported (88). In another recent study, hepatotoxicity of PIs, LPV and, RTV, was reported to interfere with ER-Golgi trafficking via inhibition of Ras converting CAAX endopeptidase-1 (RCE1) and its potential substrates, leading to cellular stress responses and fatty liver disease (89). Another possible cause of hepatotoxicity due to LPV/RTV is insufficient P450 activity to metabolize large amounts of those drugs during the treatment period. Additionally, LPV/RTV can reactivate the infections caused by hepatitis $\mathrm{B}$ and $\mathrm{C}$ viruses and lead to deterioration of the liver disease (90).

Tocilizumab causes liver damage through not wellunderstood mechanisms but its ability to block IL-6, which is an important factor in the regeneration of the liver might be the underlying mechanism of mild-to-moderate liver enzyme elevation (90). IL-6 is also known to reduce viral entry to the host cells through downregulation of the $\mathrm{Na}(+)$ /taurocholate co-transporting polypeptide (NTCP), as well as viral replication in HBV infected patients $(91,92)$. 
Consuming hydroxychloroquine in patients with porphyria cutanea tarda is associated with acute hepatotoxicity but the underlying mechanism is yet to be understood (90). Rismanbaf et al., postulated that synergy between inflammatory response to COVID-19 infection and adverse reaction to the reactive metabolite of HCQ could lead to liver injury (93).

The degree of lipophilicity, metabolization by CYP3A4 in the liver, inhibition of organic anion transporting polypeptide 1B1 (OATP1B1), p-glycoprotein (P-gp) and breast cancer resistance proteins (BCRP), all of which serve as transporters in the liver to protect it from xenobiotics, in addition to the activity of bile salt export pump (BSEP) which is involved in cholestasis process, are determining factors in estimating the hepatotoxicity of JAK inhibitors, including baricitinib, tofacitinib, upadacitinib, and ruxocitinib. In contrast to baricitinib which does not meet the criteria for hepatotoxicity in humans, tofacitinib and upadacitinib are known as more hepatotoxic agents especially in patients with underlying liver diseases or those who receive other potentially hepatotoxic drugs (84).

Furthermore, inflammatory response to the antivirals might be another probable cause of drug hepatotoxicity in COVID-19 patients (94).

\section{CONCLUSIONS}

In conclusion, to the best of our knowledge, this is the first study that has assessed the drug-induced liver injury in COVID-19 infected patients. Liver injury in COVID-19 patients could be caused by the virus itself or the administration of some types of drug. Intensive liver function monitoring should be considered

\section{REFERENCES}

1. Xu X-W, Wu X-X, Jiang X-G, Xu K-J, Ying L-J, Ma C-L, et al. Clinical findings in a group of patients infected with the 2019 novel coronavirus (SARS-Cov2) outside of Wuhan, China: Retrospective case series. BMJ. (2020) 368:m606. doi: 10.1136/bmj.m606

2. Wang D, Hu B, Hu C, Zhu F, Liu X, Zhang J, et al. Clinical characteristics of 138 hospitalized patients with 2019 novel coronavirus-infected pneumonia in Wuhan, China. JAMA. (2020) 323:1061-9. doi: 10.1001/jama.2020.1585

3. Zhou P, Yang X-L, Wang X-G, Hu B, Zhang L, Zhang W, et al. A pneumonia outbreak associated with a new coronavirus of probable bat origin. Nature. (2020) 579:270-3. doi: 10.1038/s41586-020-2951-z

4. Hoffmann M, Kleine-Weber H, Schroeder S, Krüger N, Herrler T, Erichsen $\mathrm{S}$, et al. SARS-CoV-2 cell entry depends on ACE2 and TMPRSS2 and is blocked by a clinically proven protease inhibitor. Cell. (2020) 181:271-80.e8. doi: 10.1016/j.cell.2020.02.052

5. Kulkarni AV, Kumar P, Tevethia HV, Premkumar M, Arab JP, Candia $\mathrm{R}$, et al. Systematic review with meta-analysis: liver manifestations and outcomes in COVID-19. Aliment Pharmacol Ther. (2020) 52:584-99. doi: 10.1111/apt.15916

6. Nardo AD, Schneeweiss-Gleixner M, Bakail M, Dixon ED, Lax SF, Trauner M. Pathophysiological mechanisms of liver injury in COVID-19. Liver Int. (2021) 41:20-32. doi: 10.1111/liv.14730

7. Del Zompo F, De Siena M, Ianiro G, Gasbarrini A, Pompili M, Ponziani FR. Prevalence of liver injury and correlation with clinical outcomes in patients with COVID-19: systematic review with meta-analysis. Eur Rev Med Pharmacol Sci. (2020) 24:13072-88. doi: 10.26355/eurrev_202012_24215 for patients, especially patients who are treated with drugs such as remdesivir, lopinavir/ritonavir, and tocilizumab.

\section{LIMITATIONS}

There were limited studies that reported complete and detailed data about the safety and efficacy of drugs on liver function tests. Some of the studies did not certainly report that liver injury is due to drugs and they just raise the possibility of the drug's role in the development of DILI. Some of the articles did not report DIDI based on the RUCAM and other well-known validated methods of DILI assessment. Some of the articles reported liver-related adverse events and did not determine the degree of liver injury. More studies, particularly randomized clinical trials (RCTs) are required to better understand the risk of DILI following administration of these drugs.

\section{DATA AVAILABILITY STATEMENT}

The original contributions presented in the study are included in the article/supplementary material, further inquiries can be directed to the corresponding authors.

\section{AUTHOR CONTRIBUTIONS}

FS, ZS, NK, ME, and SN contributed in title screening, abstract screening, and full text screening. FS extracted full texts data. $\mathrm{MN}, \mathrm{MM}$, and YF conducted discussion part. $\mathrm{MN}$ and YF conducted second check of each steps. All authors contributed in writing the article.

8. Mao R, Qiu Y, He J-S, Tan J-Y, Li X-H, Liang J, et al. Manifestations and prognosis of gastrointestinal and liver involvement in patients with COVID19: a systematic review and meta-analysis. Lancet Gastroenterol Hepatol. (2020) 5:667-78. doi: 10.1016/S2468-1253(20)30126-6

9. Wong YJ, Tan M, Zheng Q, Li JW, Kumar R, Fock KM, et al. A systematic review and meta-analysis of the COVID-19 associated liver injury. Ann Hepatol. (2020) 19:627-34. doi: 10.1016/j.aohep.2020.08.064

10. Youssef M. H Hussein M, Attia AS, M Elshazli R, Omar M, Zora G, et al. COVID-19 and liver dysfunction: A systematic review and meta-analysis of retrospective studies. J Medical Virol. (2020) 92:1825-33. doi: 10.1002/jmv.26055

11. Parohan M, Yaghoubi S, Seraji A. Liver injury is associated with severe coronavirus disease 2019 (COVID-19) infection: A systematic review and meta-analysis of retrospective studies. Hepatol Res. (2020) 50:924-35. doi: 10.1111/hepr.13510

12. Lei , Zhang L, Han $\mathrm{P}$, Zheng C, Tong Q, Shang H, et al. Liver injury in patients with COVID-19: clinical profiles, CT findings, the correlation of the severity with liver injury. Hepatol Int. (2020) 14:733-42. doi: 10.1007/s12072-020-10087-1

13. Ding $\mathrm{Y}, \mathrm{He} \mathrm{L}$, Zhang Q, Huang Z, Che X, Hou J, et al. Organ distribution of severe acute respiratory syndrome (SARS) associated coronavirus (SARS$\mathrm{CoV}$ ) in SARS patients: implications for pathogenesis and virus transmission pathways. J Pathol. (2004) 203:622-30. doi: 10.1002/path.1560

14. Tan Y-J, Fielding BC, Goh P-Y, Shen S, Tan THP, Lim SG, et al. Overexpression of $7 \mathrm{a}$, a protein specifically encoded by the severe acute respiratory syndrome coronavirus, induces apoptosis via a caspase-dependent pathway. J Virol. (2004) 78:14043-7. doi: 10.1128/JVI.78.24.14043-14047.2004 
15. Xu L, Liu J, Lu M, Yang D, Zheng X. Liver injury during highly pathogenic human coronavirus infections. Liver Int. (2020) 40:998-1004. doi: 10.1111/liv.14435

16. Yang L, Han Y, Nilsson-Payant BE, Gupta V, Wang P, Duan X, et al. A human pluripotent stem cell-based platform to study SARS-CoV-2 tropism and model virus infection in human cells and organoids. Cell Stem Cell. (2020) 27:125-36 e7.

17. Fan Z, Chen L, Li J, Cheng X, Yang J, Tian C, et al. Clinical features of COVID19-related liver functional abnormality. Clin Gastroenterol Hepatol. (2020) 18:1561-6. doi: 10.1016/j.cgh.2020.04.002

18. Abubakar AR, Sani IH, Godman B, Kumar S, Islam S, Jahan I, et al. Systematic review on the therapeutic options for covid-19: clinical evidence of drug efficacy and implications. Infect Drug Resist. (2020) 13:4673-95. doi: 10.2147/IDR.S289037

19. Moher D, Liberati A, Tetzlaff J, Altman DG. Preferred reporting items for systematic reviews and meta-analyses: The PRISMA statement. J Clin Epidemiol. (2009) 62:1006-12. doi: 10.1016/j.jclinepi.2009.06.005

20. Grein J, Ohmagari N, Shin D, Diaz G, Asperges E, Castagna A, et al. Compassionate use of remdesivir for patients with severe Covid-19. N Engl J Med. (2020) 382:2327-36. doi: 10.1056/NEJMoa2007016

21. Cai Q, Huang D, Yu H, Zhu Z, Xia Z, Su Y, et al. COVID-19: abnormal liver function tests. J Hepatol. (2020) 73:566-74. doi: 10.1016/j.jhep.2020.04.006

22. Sun J, Deng X, Chen X, Huang J, Huang S, Li Y, et al. Incidence of adverse drug reactions in COVID-19 patients in china: an active monitoring study by hospital pharmacovigilance system. Clin Pharmacol Ther. (2020) 108:791-7. doi: $10.1002 /$ cpt.1866

23. Wang Y, Zhang D, Du G, Du R, Zhao J, Jin Y, et al. Remdesivir in adults with severe COVID-19: a randomised, double-blind, placebocontrolled, multicentre trial. Lancet (London, England). (2020) 395:1569-78. doi: 10.1016/S0140-6736(20)31022-9

24. Antinori S, Cossu MV, Ridolfo AL, Rech R, Bonazzetti C, Pagani G, et al. Compassionate remdesivir treatment of severe Covid-19 pneumonia in intensive care unit (ICU) and Non-ICU patients: Clinical outcome and differences in post-treatment hospitalisation status. Pharmacol Res. (2020) 158:104899. doi: 10.1016/j.phrs.2020.104899

25. Durante-Mangoni E, Andini R, Bertolino L, Mele F, Florio LL, Murino P, et al. Early experience with remdesivir in SARS-CoV-2 pneumonia. Infection. (2020) 48:779-82. doi: 10.1007/s15010-020-01448-x

26. Muhović D, Bojović J, Bulatović A, Vukčević B, Ratković M, Lazović R, et al. First case of drug-induced liver injury associated with the use of tocilizumab in a patient with COVID-19. Liver Int. (2020) 40:1901-5. doi: 10.1111/liv. 14516

27. Goldman JD, Lye DCB, Hui DS, Marks KM, Bruno R, Montejano R, et al. Remdesivir for 5 or 10 days in patients with severe Covid-19. N Engl J Med. (2020) 383:1827-37. doi: 10.1056/NEJMoa2015301

28. Falcão MB, de Goes Cavalcanti LP, Filgueiras Filho NM, de Brito CAA. Case report: hepatotoxicity associated with the use of hydroxychloroquine in a patient with COVID-19. Am J Trop Med Hyg. (2020) 102:1214-6. doi: 10.4269/ajtmh.20-0276

29. Jiang S, Wang R, Li L, Hong D, Ru R, Rao Y, et al. Liver injury in critically ill and non-critically ill COVID-19 patients: a multicenter, retrospective, observational study. Front Med. (2020) 7:347. doi: 10.3389/fmed.2020. 00347

30. Wu H, Liu S, Luo $\mathrm{H}$, Chen M. Progress in the clinical features and pathogenesis of abnormal liver enzymes in coronavirus disease 2019. J Clini Translational Hepatol. (2021) 9:239-46. doi: 10.14218/JCTH.2020. 00126

31. Guaraldi G, Meschiari M, Cozzi-Lepri A, Milic J, Tonelli R, Menozzi M, et al. Tocilizumab in patients with severe COVID-19: a retrospective cohort study. Lancet Rheumatol. (2020) 2:e474-e84. doi: 10.1016/S2665-9913(20)30173-9

32. Leegwater E, Strik A, Wilms EB, Bosma LBE, Burger DM, Ottens TH, et al. Drug-induced liver injury in a COVID-19 patient: potential interaction of remdesivir with P-glycoprotein inhibitors. Clin Infect Dis. (2020) 72:1256-8. doi: $10.1093 / \mathrm{cid} /$ ciaa883

33. Dubert M, Visseaux B, Isernia V, Bouadma L, Deconinck L, Patrier J, et al. Case report study of the first five COVID-19 patients treated with remdesivir in France. International Journal of Infectious Diseases. (2020) 98:290-3. doi: 10.1016/j.ijid.2020.06.093
34. Kelly M, O'Connor R, Townsend L, Coghlan M, Relihan E, Moriarty M, et al. Clinical outcomes and adverse events in patients hospitalised with COVID19, treated with off-label hydroxychloroquine and azithromycin. Br J Clin Pharmacol. (2021) 87:1150-4. doi: 10.1111/bcp.14482

35. Lee C, Ahn MY, Byeon K, Choi J-P, Hahm C, Kim H, et al. Clinical experience with use of remdesivir in the treatment of severe acute respiratory syndrome Coronavirus 2: a case series. Infection \& Chemotherapy. (2020) 52:369-80. doi: 10.3947/ic.2020.52.3.369

36. Zampino R, Mele F, Florio LL, Bertolino L, Andini R, Galdo M, et al. Liver injury in remdesivir-treated COVID-19 patients. Hepatol Int. (2020) 1-3. doi: 10.1007/s12072-020-10077-3

37. Hundt MA, Deng Y, Ciarleglio MM, Nathanson MH, Lim JK. Abnormal liver tests in COVID-19: A retrospective observational cohort study of 1,827 patients in a major US Hospital Network. Hepatology. (2020) 72:1169-76. doi: $10.1002 /$ hep.31487

38. Carothers C, Birrer K, Vo M. Acetylcysteine for the treatment of suspected remdesivir-associated acute liver failure in COVID-19: a case series. Pharmacotherapy. (2020) 40:1166-71. doi: 10.1002/phar.2464

39. Serviddio G, Villani R, Stallone G, Scioscia G, Foschino-Barbaro MP, Lacedonia D. Tocilizumab and liver injury in patients with COVID-19. Therap Adv Gastroenterol. (2020) 13:1756284820959183. doi: $10.1177 / 1756284820959183$

40. Aiswarya D, Arumugam V, Dineshkumar T, Gopalakrishnan N, Lamech TM, Nithya G, et al. Use of remdesivir in patients with COVID-19 on hemodialysis: a study of safety and tolerance. Kidney Int Rep. (2021) 6:586-93. doi: 10.1016/j.ekir.2020.12.003

41. Yamazaki S, Suzuki T, Sayama M. Nakada T-a, Igari H, Ishii I. Suspected cholestatic liver injury induced by favipiravir in a patient with COVID-19. J Infect Chemother. (2021) 27:390-2. doi: 10.1016/j.jiac.2020.12.021

42. Hariyanto TI, Kristine E, Jillian Hardi C, Kurniawan A. Efficacy of Lopinavir/Ritonavir compared with standard care for treatment of coronavirus disease 2019 (COVID-19): a systematic review. Infect Disord Drug Targets. (2020). doi: 10.2174/1871526520666201029125725

43. Patel TK, Patel PB, Barvaliya M, Saurabh MK, Bhalla HL, Khosla PP. Efficacy and safety of lopinavir-ritonavir in COVID-19: A systematic review of randomized controlled trials. J Infect Public Health. (2021) 14:740-8. doi: 10.1016/j.jiph.2021.03.015

44. Zhu Y, Niu M, Chen J, Zou Zs, Ma Zj, Liu Sh, et al. Hepatobiliary and pancreatic: Comparison between Chinese herbal medicine and Western medicine-induced liver injury of 1985 patients. J Gastroen Hepatol. (2016) 31:1476-82. doi: 10.1111/jgh.13323

45. Hariyanto TI, Hardyson W, Kurniawan A. Efficacy and safety of tocilizumab for coronavirus disease 2019 (Covid-19) patients: a systematic review and meta-analysis. Drug research. (2021) 71:265-74. doi: 10.1055/a-13362371

46. Tleyjeh IM, Kashour Z, Riaz M, Hassett L, Veiga VC, Kashour T. Efficacy and safety of tocilizumab in COVID-19 patients: a living systematic review and meta-analysis-first update. Clin Microbiol Infect. (2021) 27:1076-82. doi: 10.1016/j.cmi.2021.04.019

47. Ridruejo E, Soza A. The liver in times of COVID-19: What hepatologists should know. Ann Hepatol. (2020) 19:353-8. doi: 10.1016/j.aohep.2020.05.001

48. Yadav DK, Singh A, Zhang Q, Bai X, Zhang W, Yadav RK, et al. Involvement of liver in COVID-19: systematic review and meta-analysis. Gut. (2021) 70:807-9. doi: 10.1136/gutjnl-2020-322072

49. Vitiello A, La Porta R, D'Aiuto V, Ferrara F. The risks of liver injury in COVID-19 patients and pharmacological management to reduce or prevent the damage induced. Egyptian Liver Journal. (2021) 11:1-6. doi: 10.1186/s43066-021-00082-y

50. Metawea MI, Yousif WI, Moheb I. COVID 19 and liver: An A$\mathrm{Z}$ literature review. Digestive and Liver Disease. (2021) 53:146. doi: 10.1016/j.dld.2020.09.010

51. Björnsson ES. Hepatotoxicity by drugs: the most common implicated agents. Int J Mol Sci. (2016) 17:224. doi: 10.3390/ijms17020224

52. Olry A, Meunier L, Délire B, Larrey D, Horsmans Y, Le Louët H. DrugInduced liver injury and COVID-19 infection: the rules remain the same. Springer. (2020). doi: 10.1007/s40264-020-00954-Z

53. Kawasuji H, Tsuji Y, Ogami C, Takegoshi Y, Kaneda M, Murai Y, et al. Association between high serum favipiravir concentrations and drug-induced 
liver injury. medRxiv. (2021). doi: 10.1101/2021.05.03.21256437. [Epub ahead of print].

54. Wong GL-H, Wong VW-S, Thompson A, Jia J, Hou J, Lesmana CRA, et al. Management of patients with liver derangement during the COVID-19 pandemic: an Asia-Pacific position statement. Lancet Gastroenterol Hepatol. (2020). doi: 10.1016/S2468-1253(20)30190-4

55. Li L, Wang $\mathrm{X}$, Wang $\mathrm{R}$, Hu Y, Jiang $\mathrm{S}$, Lu X. Antiviral agent therapy optimization in special populations of COVID-19 patients. Drug Des Devel Ther. (2020) 14:3001. doi: 10.2147/DDDT.S259 058

56. Pilkington V, Pepperrell T, Hill A, A. review of the safety of favipiravira potential treatment in the COVID-19 pandemic? J Virus Eradicat. (2020) 6:45-51. doi: 10.1016/S2055-6640(20)30016-9

57. Hassanpour S, Arab-Zozani M, Amani B, Heidarzad F, Fathalipour M, Martinez-de-Hoyo R. The efficacy and safety of Favipiravir in treatment of COVID-19: A systematic review and meta-analysis of clinical trials. medRxiv. (2021). 11:11022. doi: 10.1101/2021.02.14.21251693

58. Satsangi S, Gupta N, Kodan P. Current and New Drugs for COVID-19 Treatment and its effects on the liver. J Clin Transl Hepatol. (2021) 9:436-46. doi: 10.14218/JCTH.2020.00174

59. Charan J, Kaur RJ, Bhardwaj P, Haque M, Sharma P, Misra S, et al. Rapid review of suspected adverse drug events due to remdesivir in the WHO database; findings and implications. Expert Rev Clin Pharmacol. (2021) 14:95-103. doi: 10.1080/17512433.2021.1856655

60. Flamm SL, Yang Y-X, Singh S, Falck-Ytter YT, Committee AICG. American gastroenterological association institute guidelines for the diagnosis and management of acute liver failure. Gastroenterology. (2017) 152:644-7. doi: 10.1053/j.gastro.2016.12.026

61. Brkljacić N, Gracin S, Prkacin I, Sabljar-Matovinović M, Mrzljak A, Nemet Z. Stevens-Johnson syndrome as an unusual adverse effect of azithromycin. Acta Dermatovenerol Croat. (2006) 14(1):40-5.

62. LiverTox N: Clinical and research information on drug-induced liver injury. Bethesda (MD): National Institute of Diabetes and Digestive and Kidney Diseases. (2012).

63. Bryant A, Lawrie TA, Dowswell T, Fordham EJ, Mitchell S, Hill SR, et al. Ivermectin for prevention and treatment of COVID-19 infection: a systematic review, meta-analysis, and trial sequential analysis to inform clinical guidelines. Am J Ther. (2021) 28:e434-e60. doi: 10.1097/MJT.0000000000001402

64. Okumuş N, Demirtürk N, Çetinkaya RA, Güner R, Avci I Y, Orhan S, et al. Evaluation of the effectiveness and safety of adding ivermectin to treatment in severe COVID-19 patients. BMC Infect Dis. (2021) 21:411. doi: 10.1186/s12879-021-06104-9

65. Popp M, Stegemann M, Metzendorf MI, Gould S, Kranke P, Meybohm P, et al. Ivermectin for preventing and treating COVID-19. The Cochrane database of systematic reviews. (2021) 7:Cd015017. doi: 10.1002/14651858.CD0 15017

66. Roman YM, Burela PA, Pasupuleti V, Piscoya A, Vidal JE, Hernandez AV. Ivermectin for the treatment of COVID-19: A systematic review and metaanalysis of randomized controlled trials. Clin Infect Dis. (2021) ciab591. doi: 10.1101/2021.05.21.21257595

67. Veit O, Beck B, Steuerwald M, Hatz C. First case of ivermectininduced severe hepatitis. Trans R Soc Trop Med Hyg. (2006) 100:795-7. doi: 10.1016/j.trstmh.2006.02.003

68. Hariyanto TI, Halim DA, Jodhinata C, Yanto TA, Kurniawan A. Colchicine treatment can improve outcomes of coronavirus disease 2019 (COVID-19): A systematic review and meta-analysis. Clin Exp Pharmacol Physiol. (2021) 48:823-30. doi: 10.1111/1440-1681.13488

69. Vitiello A, Ferrara F. Colchicine and SARS-CoV-2: Management of the hyperinflammatory state. Respir Med. (2021) 178:106322. doi: 10.1016/j.rmed.2021.106322

70. Mareev VY, Orlova YA, Plisyk AG, Pavlikova EP, Akopyan ZA, Matskeplishvili ST, et al. Proactive anti-inflammatory therapy with colchicine in the treatment of advanced stages of new coronavirus infection. The first results of the COLORIT study. Kardiologiia. (2021) 61:15-27. doi: 10.18087/cardio.2021.2.n1560

71. Golpour M, Mousavi T, Alimohammadi M, Mosayebian A, Shiran M, Alizadeh Navaei R, et al. The effectiveness of Colchicine as an antiinflammatory drug in the treatment of coronavirus disease 2019: Metaanalysis. Int J Immunopathol Pharmacol. (2021) 35:20587384211031763. doi: $10.1177 / 20587384211031763$

72. Karatza E, Ismailos G, Karalis V. Colchicine for the treatment of COVID-19 patients: efficacy, safety, and model informed dosage regimens. Xenobiotica. (2021) 51:643-56. doi: 10.1080/00498254.2021.1909782

73. Schlesinger N, Firestein BL, Brunetti L. Colchicine in COVID-19: an old drug, new use. Current Pharmacology Reports. (2020) 1-9. doi: 10.1007/s40495-020-00225-6

74. Xu Z, Shi L, Wang Y, Zhang J, Huang L, Zhang C, et al. Pathological findings of COVID-19 associated with acute respiratory distress syndrome. Lancet Respir Med. (2020) 8:420-2. doi: 10.1016/S2213-2600(20)30076-X

75. Fromenty B, Pessayre D. Inhibition of mitochondrial beta-oxidation as a mechanism of hepatotoxicity. Pharmacol Ther. (1995) 67:101-54. doi: 10.1016/0163-7258(95)00012-6

76. Pessayre D, Fromenty B, Berson A, Robin M-A, Lettéron P, Moreau R, et al. Central role of mitochondria in drug-induced liver injury. Drug Metab Rev. (2012) 44:34-87. doi: 10.3109/03602532.2011.604086

77. FitzGerald GA. Misguided drug advice for COVID-19. Science. 2020;367(6485):1434-. doi: 10.1126/science.abb8034

78. Fang L, Karakiulakis G, Roth M. Are patients with hypertension and diabetes mellitus at increased risk for COVID-19 infection? Lancet Respir Med. (2020) 8:e21. doi: 10.1016/S2213-2600(20)30116-8

79. Massart J, Begriche K, Moreau C, Fromenty B. Role of nonalcoholic fatty liver disease as risk factor for drug-induced hepatotoxicity. J Clin Trans Res. (2017) 3:212. doi: 10.18053 /jctres.03.2017S1.006

80. Michaut A, Moreau C, Robin MA, Fromenty B. Acetaminophen-induced liver injury in obesity and nonalcoholic fatty liver disease. Liver Int. (2014) 34:e171-e9. doi: 10.1111/liv.12514

81. El-Ghiaty MA, Shoieb SM, El-Kadi AO. Cytochrome P450mediated drug interactions in COVID-19 patients: Current findings and possible mechanisms. Med Hypotheses. (2020) 144:110033. doi: 10.1016/j.mehy.2020.110033

82. Yang R-X, Zheng R-D, Fan J-G. Etiology and management of liver injury in patients with COVID-19. World J Gastroenterol. (2020) 26:4753. doi: 10.3748 /wjg.v26.i32.4753

83. Guan G, Gao L, Wang J, Wen X, Mao T, Peng S, et al. Exploring the mechanism of liver enzyme abnormalities in patients with novel coronavirusinfected pneumonia. Zhonghua Gan Zang Bing Za Zhi. (2020) 28:100-6. doi: 10.3760/cma.j.issn.1007-3418.2020.02.002

84. Raschi E, Caraceni P, Poluzzi E, De Ponti F. Baricitinib, JAK inhibitors and liver injury: a cause for concern in COVID-19? Expert Opin Drug Saf. (2020) 19:1367-9. doi: 10.1080/14740338.2020.18 12191

85. Griffin LM, Watkins PB, Perry CH, Claire RLS, Brouwer KL. Combination lopinavir and ritonavir alter exogenous and endogenous bile acid disposition in sandwich-cultured rat hepatocytes. Drug Metabolism and Disposition. (2013) 41:188-96. doi: 10.1124/dmd.112.047225

86. Huisman MT, Smit JW, Crommentuyn KM, Zelcer N, Wiltshire HR, Beijnen $\mathrm{JH}$, et al. Multidrug resistance protein 2 (MRP2) transports HIV protease inhibitors, and transport can be enhanced by other drugs. Aids. (2002) 16:2295-301. doi: 10.1097/00002030-200211220-00009

87. Ye Zw, Camus S, Augustijns P, Annaert P. Interaction of eight HIV protease inhibitors with the canalicular efflux transporter ABCC2 (MRP2) in sandwich-cultured rat and human hepatocytes. Biopharmaceut Drug Disposit. (2010) 31:178-88. doi: 10.1002/bdd.701

88. Holmstock N, Oorts M, Snoeys J, Annaert P. MRP2 inhibition by HIV protease inhibitors in rat and human hepatocytes: a quantitative confocal microscopy study. Drug Metab Dispos. (2018) 46:697-703. doi: $10.1124 /$ dmd.117.079467 
89. Khalatbari A, Mishra P, Han H, He Y, MacVeigh-Aloni M, Ji C. Ritonavir and lopinavir suppress RCE1 and CAAX Rab proteins sensitizing the liver to organelle stress and injury. Hepatol Commun. (2020) 4:932-44. doi: 10.1002/hep4.1515

90. Kudaravalli P, Saleem SA, Ibeche B, John S. Case series and review of liver dysfunction in COVID-19 patients. Eur J Gastroenterol Hepatol. (2020) 32:1244-50. doi: 10.1097/MEG.0000000000001806

91. Kuo T-M. Hu C-p, Chen Y-L, Hong M-H, Jeng K-S, Liang C-CT, et al. HBV replication is significantly reduced by IL-6. J Biomedical Sci. (2009) 16:1-9. doi: 10.1186/1423-0127-16-41

92. Bouezzedine F, Fardel O, Gripon P. Interleukin 6 inhibits HBV entry through NTCP down regulation. Virology. (2015) 481:34-42. doi: 10.1016/j.virol.2015.02.026

93. Rismanbaf A, Zarei S. Liver and kidney injuries in COVID-19 and their effects on drug therapy; a letter to editor. Arch Acad Emerg Med. (2020) 8:e17. doi: 10.22037/aaem.v8i1.590

94. Gholizadeh P, Safari R, Marofi P, Zeinalzadeh E, Pagliano P, Ganbarov K, et al. Alteration of liver biomarkers in patients with SARS-CoV-2 (COVID-19). J Inflamm Res. (2020) 13:285. doi: 10.2147/JIR.S257078
Conflict of Interest: The authors declare that the research was conducted in the absence of any commercial or financial relationships that could be construed as a potential conflict of interest.

Publisher's Note: All claims expressed in this article are solely those of the authors and do not necessarily represent those of their affiliated organizations, or those of the publisher, the editors and the reviewers. Any product that may be evaluated in this article, or claim that may be made by its manufacturer, is not guaranteed or endorsed by the publisher.

Copyright (C) 2021 Sodeifian, Seyedalhosseini, Kian, Eftekhari, Najari, Mirsaeidi, Farsi and Nasiri. This is an open-access article distributed under the terms of the Creative Commons Attribution License (CC BY). The use, distribution or reproduction in other forums is permitted, provided the original author(s) and the copyright owner(s) are credited and that the original publication in this journal is cited, in accordance with accepted academic practice. No use, distribution or reproduction is permitted which does not comply with these terms. 